\title{
"THE PRIMARY RESPONSIBILITY OF THE LICENCE HOLDER": A PRINCIPLE OF EUROPEAN NUCLEAR LAW
}

\author{
DOI:10.24193/SUBBiur.62(2017).3.4 \\ Published Online: 2017-09-30 \\ Published Print: 2017-09-30
}

Handrlica JAKUB*

\begin{abstract}
The very special nature of radioactive waste triggers variable challenges to the allocation of responsibilities between the state and waste generators. To identify some clear delineation between the responsibility of the waste generator (operator of nuclear power plant, of a research reactor, reprocessing facility, or other industrial or medical licence holder) and that of the concerned state to protect its citizens, this contribution turns its attention to the legal framework created in this field of by means of European law. In order to identify some clear delineation between the responsibility of the waste generator (licence holder) and that of the state to protect its citizens, we turn our attention to the legal framework created in the field of radioactive waste management by means of European law. In the following parts, major legal instruments will be examined, analysing the allocation of responsibility between the waste generator and the state in whose territory radioactive waste is produced.
\end{abstract}

Keywords: radioactive waste management, primary responsibility of the licence holder, ultimate responsibility of the state.

\section{Introduction ${ }^{1}$}

Currently, fourteen out of the twenty eight Member States of the European Union have nuclear power plants in operation, and a further two have nuclear power plants which are being decommissioned. ${ }^{2}$ At the same time, some of Member States already have official phase-out policies, such as Germany, or a de facto phase-out situation where no replacement capacity is planned as current nuclear power plants are closed, such as Spain. Three Member States (Finland, France and the Slovak Republic) are constructing new nuclear power plants. Bulgaria, the Czech Republic, Lithuania, the Netherlands, Romania and the United Kingdom are planning the construction of new units, while also Hungary, Italy, Poland, Slovenia are considering proposals for new build. Nuclear power generation and its associated processes e.g. fuel manufacture, reprocessing and decommissioning are to be 
considered the largest generators of radioactive waste. However, radioactive waste is also generated as a result of non-power uses of radioactive materials, such as the manufacture of radioactive materials for use in medical and industrial applications, or research facilities such as laboratories, research reactors, etc. Therefore, in total, some 2500 tonnes of radioactive waste in a form of heavy metal and $110700 \mathrm{m3}$ of other radioactive waste are generated in the European Union each year. ${ }^{3}$

It is a matter of fact, that the very special nature of radioactive waste triggers variable challenges to the allocation of responsibilities between the state, which permitted the concerned activity in its territory and the waste generators, than is usual by conventional types of wastes, such as municipal (household, commercial and demolition), by clinical wastes and also by certain other hazardous wastes (electronic, etc.). In general, the "polluter pays" principle applies to waste generators in most of the jurisdictions. ${ }^{5}$ However, in the field of radioactive waste management, governments basically do not limit their involvement to the pure creation of legislative and regulatory frameworks. Given their longevity, radioactive waste introduces a "new time dimension in the field of radiation risk management." ${ }^{16}$ Whatever the future of nuclear power and other nuclear non-power applications, the implementation of disposal solutions, as the end of managing radioactive waste, are needed for assuring both safety and sustainability. Only adequate disposal provides workers, the public and the environment with protections from the hazards radioactive waste may pose over time. Consequently, governments must bear the overall responsibility for formulating and implementation comprehensive national policies for long-term management of radioactive waste, reflecting the interests and positions of all affected parties. ${ }^{7}$

In order to identify some clear delineation between the responsibility of the waste generator and that of the state to protect its citizens, we turn our attention to the legal framework created in the field of radioactive waste management by means of European law. In the following parts, major legal instruments will be examined, analysing the allocation of responsibility between the waste generator and the state in whose territory radioactive waste is produced.

\section{The principle of "primary responsibility" of the licence holder}

In the field of international law, the legal framework created under the auspices of the International Atomic Energy Agency (IAEA) is to be analysed to tackle the question of how responsibilities are distributed among the polluters and the state, regarding radioactive waste. Here, the Joint Convention on the Safety of Spent Fuel Management and on the Safety of Radioactive Waste Management of $1997^{8}$ plays an eminent role, its having been adopted as one of the salient reactions of the international community of states on the accident in Chernobyl. ${ }^{9}$ The Joint Convention intents to address the issues of safety of radioactive waste management "through the enhancement of national measures and international co-operation, including where appropriate, safety-related technical cooperation." Further, it also intends to "ensure that during all stages of spent fuel and 
radioactive waste management there are effective defenses against potential hazards so that individuals, society and the environment are protected from harmful effects of ionizing radiation, now and in the future, in such a way that the needs and aspirations of the present generation are met without compromising the ability of future generations to meet their needs and aspirations" and to "to prevent accidents with radiological consequences and to mitigate their consequences should they occur during any stage of spent fuel or radioactive waste management." Consequently, the Joint Convention is the first legal instrument to address the issue of spent fuel and radioactive waste management safety on a global scale.

The Joint Convention shall apply to the radioactive waste those results from the operation of civilian nuclear reactors or from other civilian applications. ${ }^{10}$ Consequently, wastes resulting from the operation of any military nuclear facilities are not to be covered by the provisions of this Convention, unless declared as radioactive waste for the purposes of this Convention by the respective Contracting Party. Further, neither is the radioactive waste held at reprocessing facilities as part of a reprocessing activity covered in the scope of this Convention, unless the Contracting Party declares reprocessing to be part of radioactive waste management. Under the scope of the Convention, also do not fall any waste that contains only naturally occurring radioactive materials and that does not originate from the nuclear fuel cycle, unless it constitutes a disused sealed source or it is declared as radioactive waste for the purposes of this Convention by the Contracting Party. ${ }^{11}$

The Joint Convention follows the concept of the "ultimate responsibility" of the state, stipulating that each Contracting Party shall provide for the establishment of applicable national safety requirements and regulations for radiation safety, which will cover national licensing systems, prohibition of the operation of a radioactive waste management facility without a licence, a system of appropriate institutional control, regulatory inspection, documentation and reporting, the enforcement of applicable regulations and of the terms of the licences and clear allocation of responsibilities of the bodies involved in the different steps of radioactive waste management. ${ }^{12}$ In relation to allocation of responsibility between the waste producer and the state, the Joint Convention explicitly declares ${ }^{13}$ that "each Contracting Party shall ensure that prime responsibility for the safety of spent fuel or radioactive waste management rests with the holder of the relevant licence and shall take the appropriate steps to ensure that each such licence holder meets its responsibility" (emphasis added). As the "licence" is to be considered as "any authorization, permission or certification granted by a regulatory body to carry out any activity related to management of radioactive waste ${ }^{\text {"14 }}$, we deduce that the "polluter" and the "licence holder" are one and same person. ${ }^{15}$ Both those subjects to private and public law can be involved in the field of radioactive waste management. The Joint Convention takes the position of the state into consideration (and enables it), when stipulating for the "effective independence of the regulatory functions from other functions where organizations are involved in radioactive waste management and in their regulation"16.

However, it is a matter of fact that the Joint Convention does not provide for further definition of the licence holders "prime responsibility". As each Contracting Party 
must "establish and maintain a legislative and regulatory framework to govern the safety of radioactive waste management ${ }^{\prime 17}$, it is understood that shaping a precise definition of this „prime responsibility" is in the hands of the respective Contracting Party. Consequently, the Joint Convention deliberately fails to channel the major responsibilities to the "licence holder" (polluter), but remains (also deliberately) neutral in this regard, enabling the Contracting Parties to decide upon the type and range of state involvement in the field of radioactive waste management. E.g., the Contracting Party is basically free to decide on the form of a financing scheme in this area. Similarly, the Contracting Party is free to decide whether the necessary research and development will be conducted by the state, or by the licence holder. Such a neutral construction clearly reflects the fact, that when adopting the Convention, different states had already developed various financial and organisational systems in the field of radioactive waste management. Last but not least, the Joint Convention explicitly provides that, if there is no licence holder or "other responsible party", the responsibility rests with the Contracting Party that has jurisdiction over the radioactive waste. ${ }^{18}$ Thus, this rule also reflects the concept of the "ultimate responsibility" of the state, which points to potential hazards that may arise during the long-term operation of storages and repositories.

In this connection, reference may also be made to the Convention on Nuclear Safety of 1994, which provides for the same principle in relation to holders of a licence for the operation of a nuclear power plant. ${ }^{19}$

The concept of the "prime responsibility" of the state licence holder and of the "ultimate responsibility" of the state has been receipted also in provisions, created in the framework of the European Atomic Energy Community (Euratom). It is a matter of fact, that the European Atomic Energy Community and all Member States with exception of Malta are currently Contracting Parties to the Joint Convention, with Portugal (2009) and Cyprus (2010) having become a Contracting Party only recently. In this regards, the European Parliament stated in $\mathbf{2 0 0 7}$ that it "regrets the absence of a legislative corpus on harmonised standards for nuclear safety, the management of radioactive waste" and "calls on the Commission and the Member States to finally make progress on the issue of final disposal". In the "2007 Report on Assessing Euratom - 50 Years of European nuclear energy policy"20, the European Parliament invited the Commission "to review the relevant drafts of its legislative proposal and submit new proposals for Directives on the safety of nuclear facilities, on waste management, and on closure and decommissioning of nuclear facilities taking into account the 'polluter-pays' principle". Further, also the European Economic and Social Committee expressed "an urgent need for Member States utilising nuclear power to put in place national plans for management of nuclear fuel and radioactive waste. Anything else is to be seen as irresponsibly passing on the present generations' obligations to next generations". The provisions of the Council Directive 2011/70/Euratom of 19 July 2011 establishing a Community framework for the responsible and safe management of spent fuel and radioactive waste ${ }^{21}$ reflects these developments and for the first time, it creates a comprehensive framework of minimal requirements for the safe management of spent 
fuel and radioactive waste in the European Union. Pursuant to the Directive, Member States shall ensure that the prime responsibility for the safety of spent fuel and radioactive waste management facilities and/or activities rest with the licence holder. That responsibility cannot be delegated.

Consequently, the principle of the "primary responsibility" of the licence holder for radioactive waste management is to be considered a common principle of European nuclear law. ${ }^{22}$ However, similar to the Joint Convention, the Directive also fails to provide for a clearcut between the "primary responsibility" of the licence holder and the "ultimate responsibility" of the state. The Member States have a rather broad discretion upon the shaping and specification of both organisational (e.g. research, development, operation of the final disposal facilities) and financial responsibilities between the state and the licence holder. This is confirmed by the wording of the Art. 9, which provides that the Member States shall ensure that the national framework requires that adequate financial resources be available when needed for the implementation of national programmes, especially for the management of SF and RAW, "taking due account of the responsibility of spent fuel and radioactive waste generators. "It is a matter of fact, that the principle of "primary responsibility" of the licence holder finds a variety of applications in the concerned Member States:

$1 /$ Any allocation of responsibilities between the state and waste generators represents a considerable challenge to the field of radioactive waste management. Existing binding legal instruments fail to provide for an exact determination between the "primary responsibility" of the waste generator (licence holder) and the "ultimate responsibility" of the state.

Under current Finnish legislation, the Nuclear Energy Act of 1988 provides that a licence holder, whose operations generate or have generated radioactive waste, shall be responsible for all management measures and their appropriate preparation, as well as their costs. Basically, this "primary responsibility" expires when the final disposal of radioactive waste and the decommissioning of a nuclear facility has been carried out in accordance with the safety regulations, and the licensee under a waste management obligation has paid a lump sum to the State for the monitoring and control of the nuclear waste. The Finish legal framework provides for licence holder responsibility for radioactive waste management in the course of (long-term) storage, until their final disposal. Such a construction triggered considerable efforts of the licence holders to address the challenges arising from SF and RAW management. Therefore, in 1995, two major NPP licence holders (Teollisuuden Voima Oyj and Fortum Power \& Heat Oy) together established a waste management company „Posiva Oy.“ Posiva has been held responsible for research into the final disposal of spent nuclear fuel and for the construction, operation and eventual decommissioning and dismantling of the final disposal facility.

The French legal framework opted for a rather different model than the Finish legislation described above. In the French legislation, the Planning Act on sustainable management of radioactive materials and waste of $2006^{23}$ provides that the National Radioactive Waste Management Agency (L'Agence nationale pour la gestion des déchets radioactifs), a public industrial and commercial establishment (établissement public 
industriel et commercial), is responsible for the long-term management of radioactive waste. The Agency shall fulfil duties regarding managing existing long-term storage centres (either directly or by means of third parties acting on its behalf), designing, installing and building new storage centres, bearing in mind the long-term prospects for the production and management of waste. Consequently, despite the proclamation, that the "producers of spent fuels and radioactive wastes are responsible for these substances, without prejudice to the responsibility their holders have as nuclear activity operators" (Art. 2 par. 3), the Planning Act on sustainable management of radioactive materials and waste provides for a centralised, state controlled system of management, beginning with the long-term storage of these wastes and ending with their disposal in the repository. Thus, the "primary responsibility" of the waste producers is rather limited to various financial obligations vis-á-vis the Agency and the state. Thus, in contrast to the Finish system, where the licence holders bear an overall responsibility for the produced RAW and SF until these are disposed into the (final) repository in accordance with the safety regulations, the French system provides for an integrated, state controlled system of RAW and SF management. The "primary responsibility" of the licence holders is reduced to pure financial obligations.

In the legislative framework of the Czech Republic, the Nuclear Energy Act of 2017 provides that the licence holder shall bear all costs associated with its management, from its time of origin to its disposal, including monitoring of radioactive waste repositories after their closure, as well as necessary research and development activities. Under the terms of this Act, the state "guarantees safe disposal of all radioactive waste, including monitoring and supervision of repositories after their closure." While the (long-term) storage of radioactive waste remains the responsibility of waste generators, managing final repositories (including pursuing the option of the deep-geological repository) falls under the responsibility of the Radioactive Waste Repository Authority (Správa úložišt' radioaktivnich odpadů). Consequently, in the Czech Republic, the "primary responsibility" of the licence holders is reflected not only in their financial obligations, but also in their obligation to transfer the RAW and SF to the custody of the Authority in certain quality, in accordance with the safety regulations. The concept of the "ultimate responsibility" of the state has been reflected by establishment of the Authority, which has been entrusted to custody the radioactive waste, manage the research and development activities and pursue the option of the final deep-geological repository.

2/ It seems clear that licence holders" "primary responsibility" entails (at least) financial responsibility. In this regard, it is worth to mention, that the Commission presented its first report to the European Parliament on the use of financial resources earmarked for the decommissioning of nuclear power plants already in $2004 .{ }^{24}$ With respect to this article of this study, the reports included following findings:

The collected data showed that ten Member States chose the option of external management; i.e. separate from the accounts of the nuclear operator, ${ }^{25}$ which is considered to be a mode of management offering the greatest transparency and probably the best guarantee as to the ultimate use of financial resources, particularly in the event 
of an Licence holder going bankrupt. Most of these funds were segregated from revenues obtained on the basis of nuclear activities - primarily through a levy - during the plant's operational life. However, there are several notable variations; e. g. in Italy, Slovak Republic, Bulgaria and Lithuania, the funding for decommissioning and waste management is provided by more than one system. Further, in France and Germany, financial resources earmarked for decommissioning are entered into the accounts of the electricity producers, in the form of provisions (internal management). This mode of management allows very flexible use to be made of resources. It means that the same entity, in this instance the nuclear operator, has both financial and technical responsibility. However, it does not offer the same transparency as external management. A priori, it does not ensure that the resources will be available when the time comes or that they will not be used for purposes other than those for which they were created. Technically, the options for using these resources are vast and could possibly give rise to anti-competitive practices on the internal markets in electricity,

These differences between Member States are largely explained by historic factors, stemming from the economic context which preceded the creation of the internal market in electricity. "The polluter-pays-principle requires operators to set up adequate funds, which are available when necessary. This principle is not always strictly applied, usually for well-defined historic reasons (...) Differences in decommissioning strategies and fund management may lead to a distortion on the liberalised EU energy markets. Decommissioning costs, including the final disposal of the waste, must be seen as part of electricity production costs and should be compatible with state aid rules.." 26 Therefore, following consultation with Member State experts and taking advantage of its research in the field, the Commission adopted a Recommendation on decommissioning funds in $2006 .{ }^{27}$ It proposes measures to ensure that adequate financial resources are available at the scheduled time for all decommissioning activities of nuclear installations and for the management of spent fuel and radioactive waste. Pursuant to this Recommendation, "the polluter pays principle should be fully applied throughout the decommissioning of nuclear installations. In this regard, the primary concern of nuclear operators should be to ensure the availability of adequate financial resources for safe decommissioning by the time the respective nuclear installation is permanently shut down ".28

3/ In strict contrast to a rather reserved definition of licence holders "prime responsibility" for the safety of radioactive waste management in the Joint Convention and in the Directive, the existing nuclear third party liability treaties channel all liability for damages (arising from a nuclear incident) in the "nuclear installation" to the person designated or recognised by the competent public authority as being the "operator of the installation." Thus, the operator of a reprocessing and storage facility is exclusively liable for all damages, arising from the radioactive, toxic, explosive or other hazardous properties of nuclear fuel, or radioactive products, or waste, or with any of them, or from ionizing radiations emitted by any source of radiation inside these installations.

It is a matter of fact, that the relation between nuclear third party liability treaties and radioactive waste management has been the subject of long academic discussion. ${ }^{29}$ There is no 
EU legislation in this field currently. The core of these discussions represents the issue of the applicability of these conventions to those facilities where the radioactive waste are temporary stored, or definitively disposed. ${ }^{30}$ Under the legal framework of the Paris Convention on Third Party Liability in the Field of Nuclear Energy, the following facilities („nuclear installations “) are covered: „reactors other than those comprised in any means of transport; factories for the manufacture or processing of nuclear substances; factories for the separation of isotopes of nuclear fuel; factories for the reprocessing of irradiated nuclear fuel; facilities for the storage of nuclear substances other than storage incidental to the carriage of such substances; and such other installations in which there are nuclear fuel or radioactive products or waste as the Steering Committee for Nuclear Energy of the Organisation shall from time to time determine. "31 The Vienna Convention on Civil Liability for Nuclear Damage provides for a very similar definition of the same term: „any nuclear reactor other than one with which a means of sea or air transport is equipped for use as a source of power, whether for propulsion thereof or for any other purpose; any factory using nuclear fuel for the production of nuclear material, or any factory for the processing of nuclear material, including any factory for the re-processing of irradiated nuclear fuel; and any facility where nuclear material is stored, other than storage incidental to the carriage of such material. ${ }^{\text {32 }}$

Consequently, both liability treaties basically apply to the reprocessing facilities and to facilities, where radioactive waste has been temporary stored since the 1960s. However, neither treaty explicitly addressed the issue of the final disposal facilities (repositories), which became gradually more and more relevant over the course of the last decades. ${ }^{33}$ This challenge was reflected by both the Protocol to Amend the Vienna Convention on Civil Liability for Nuclear Damage of $1997^{34}$ and the Protocol to Amend the Paris Convention on Third Party Liability in the Field of Nuclear Energy of $2004 .{ }^{35}$ In the legal framework of the Amended Vienna Convention, the Board of Governors of the International Atomic Energy Agency was empowered to determine which installations with nuclear fuel, Radioactive products or waste are to be considered "nuclear installations" in the sense of the treaty. That brings the possibility of also extending the application of the treaty to waste repositories. ${ }^{36}$ The Amended Paris Convention also extended the definition of the "nuclear installation" to "installations for the disposal of nuclear substances." However, the progressive effects of these changes are rather limited in reality, as only three Member States belong to the legal framework created by the Amended Vienna Convention (Latvia, Poland and Romania). Further, the Amended Paris Convention has not yet entered into force.

Both liability systems allow only very limited liability exonerations (armed conflict, hostilities, civil war, insurrection, grave natural disaster of an exceptional character). Further, in contrast to a vague limitation of financial obligations among the state and polluter in the Joint Convention, the nuclear third party liability treaties unambiguously prefer the direct allocation of financial responsibilities on the operators' part. Therefore, the operator is obliged to have and maintain some other financial security in order to cover his exclusive liability.

However, neither of the nuclear liability treaties create a liability system free of state intervention. On contrary, the treaties provide for a whole range of interventions 
from the side of the Contracting Parties, which shape the contours of operator liability: As a quid pro quo for the principle of exclusive liability and for very limited liability relief, the Contracting Party must limit operator liability for damages under the Paris Convention of $1960 .{ }^{37}$ The same system also applies, in slightly modified form, under the Vienna Convention of 1963, which enables the Contracting Parties to limit the operator liability, ${ }^{38}$ or to provide for unlimited operators liability. To cover operator liability under the Paris Convention of 1960, the operator shall be required to have and maintain insurance or other financial security of the amount established and of such type and terms as the Contracting Party provides. ${ }^{39}$ Also, under the Vienna Convention of 1963, the operator shall be required to maintain insurance or other financial security covering his liability for nuclear damage in such amounts, of such types and in such terms as the Contracting Party shall specify. ${ }^{40}$ However, in contrast to the Paris Convention of 1960, the Vienna Convention of 1963 also provides that the Contracting Party shall ensure the payment of claims for compensation for nuclear damage that have been established against the operator by providing the necessary funds to the extent that the yield of insurance or other financial security is inadequate to satisfy such claims, but not in excess of the limit established in national legislation. Further, the Vienna Convention of 1963 provides that nothing shall require a Contracting Party or any of its constituent sub-divisions, such as States or Republics, to maintain insurance or other financial security to cover their liability as operators.

Consequently, though the nuclear third party liability conventions link liability for damages directly to the operator, they also provide a rather wide field of state intervention and basically assign their Contracting Parties to define these rules in national legislation. ${ }^{41}$ Thus, even in the field of liability for damages that may occur by operating the facilities serving for reprocessing of spent fuel, storage and final disposal, international law itself fails to provide a clear cut between operator liability and state responsibility to protect. Further, liability limitations and a system of state guarantees represent a major modification to the "polluter pays" principle in this area.

Also, while not exactly stipulated in the provision of the treaties, in the area of damage compensation, certain "ultimate responsibility" rests in the state. Nemo dat quot not habet. Even by opting for the regime of unlimited liability (which is possible under the Vienna Convention in both 1963 and 1997 versions) and under the Amended Paris Convention, after the financial funds of the operator are exhausted, any remaining damages remain a burden of the state, depending on its solvency and willingness to cover them. Further, within the meaning of the liability treaties, each disposal facility must have an operator liable with financial coverage of his liability. The question raised th th stage is to determine, who in this system must ensure that there will be the effective and continuous presence of an operator liable. Here, the treaties provide for no explicit answer to this question, however, the very definition of a nuclear operator entails a specific obligation of a state to designate or recognise an operator for any nuclear installation. Consequently, it would be reasonable to consider by extension, that this provision also includes the obligation to ensure, that someone will always remain liable for the radioactive waste disposed of. One 
possibility envisaged is that this liability be transferred to the state or a public agency it has designated. ${ }^{42}$ In this scenario, victims would have no other recourse but to claim compensation directly from the state where the radioactive waste disposal facility is located.

\section{Conclusions}

Taking the above presented perspectives into consideration, one can argue that any allocation of responsibilities between the state and waste generators represents a considerable challenge to the field of radioactive waste management. ${ }^{43}$ Existing binding legal instruments of international law fail to provide for an exact determination between the "primary responsibility" of the waste generator (licence holder) and the "ultimate responsibility" of the state. Notwithstanding the "ultimate responsibility" of the state, under the polluter pays principle, the generators are responsible for managing the waste. It seems clear that licence holders' "primary responsibility" entails (at least) financial responsibility. "Beyond this core, the contours of the polluter pays principle become blurred." 44 It is commonly held that the polluters pays principle is, in the field of radioactive waste management, subject to further shaping and specification by the state and therefore its function is rather to "justify the imposition of physical or operational responsibility on waste generators." ${ }^{45}$ Such responsibility seems to be common as regards interim storage (which is also not the case of all jurisdictions), but may be extended to final disposal and/or to research and development obligations. A vice versa, the obligations mentioned can also rest in the state. This possible extension shows that there is no a clear-cut borderline between the polluter pays principle and the state obligation to protect in this field.

In any case, the state bears its "ultimate responsibility" once the radioactive waste have finally been disposed into the repository, if responsible polluter is not known, does not exist, ceases or has become unable to duly fulfil his obligations.

\footnotetext{
* JUDr. Jakub Handrlica, Ph.D., Assistant Professor, Department of Administrative Law, The Faculty of Law, Charles University, Czech Republic. Email: jakub.handrlica@prf.cuni.cz.

${ }^{1}$ This article has been supported by the Czech Science Foundation - GACR through its project N. 17$16764 S$ „Radioactive waste and spent nuclear fuel management - identifying challenges for the Czech legal framework."

${ }^{2}$ Member States that have nuclear power plants in operation are: Belgium, Bulgaria, Czech Republic, Finland, France, Germany, Hungary, the Netherlands, Romania, Slovenia, Spain, Sweden and the United Kingdom. Italy and Lithuania have only nuclear power plants under decommissioning.

${ }^{3}$ It should be mentioned, that these figures does not include RAWs, arising from the operation of military nuclear facilities in France and in the United Kingdom.

${ }^{4}$ Riley, P. Nuclear Waste: Law, Politics and Pragmatism, Ashgate Publishing Company, Burlington, 2004, at pp. 33-56.

${ }^{5}$ Montjoie, M. Droit international et gestion des déchets radioactifs, L.G.D.J., Paris 2011, at p. 60.
} 
${ }^{6}$ Vial, E. 'Le concept de responsabilité envers les générations futures dans la gestion et le stockage des déchets radioactifs', Bulletin de droit nucléaire), 2004, at p. 16.

${ }^{7}$ Kelson, J. 'State Responsibility and the Abnormally Dangerous Activity', Harvard International Law Journal, 1972, at p. 199.

${ }^{8}$ The Joint Convention on the Safety of Spent Fuel Management and on the Safety of Radioactive Waste Management of $24^{\text {th }}$ December 1997 entered into force on $18^{\text {th }}$ June 2001 . The Convention was adopted under the auspices of the International Atomic Energy Agency and covers a number of states worldwide (Albania, Argentina, Armenia, Australia, Belarus, Belgium, Bosnia and Herzegovina, Botswana, Brazil, Bulgaria, Canada, Chile, China, Croatia, Cyprus, Czech Republic, Denmark, Estonia, Finland, France, Gabon, Georgia, Ghana, Gabon, Greece, Hungary, Iceland, Indonesia, Ireland, Italy, Japan, Jordan, Kazakhstan, Korea, Kyrgyzstan, Latvia, Lesotho, Lithuania, Luxembourg, Madagascar, Macedonia, Malta, Mauritania, Mauritius, Montenegro, Morocco, Netherlands, Niger, Nigeria, Norway, Oman, Peru, Poland, Portugal, Moldova, Romania, South Africa, Spain, Sweden, Switzerland, Tajikistan, Ukraine, UAE, United Kingdom, USA, Uruguay, Uzbekistan, Vietnam).

${ }^{9}$ Kageneck, A., Pinel, C. 'The Joint Convention on the Safety of Spent Fuel Management and on the Safety of Radioactive Waste Management', International and Comparative Law Quarterly, 1998, at p. 410.

${ }^{10}$ Art 3, Par. 1 and 2.

${ }^{11}$ Tonhauser, W., Jankowitsch-Prevor, O. 'The Joint Convention on the Safety of SF Management and on the Safety of RAW Management', in OECD (ed.), International Nuclear Law in the PostChernobyl Period, OECD, Paris 2006, at pp. 208-209.

${ }^{12}$ Art. 19, Par. 1.

${ }^{13}$ Art. 21, Par. 1.

${ }^{14}$ Art. 2, letter /e/.

${ }^{15}$ Cans, Ch. 'Droit nucléaire et droit de l'environnement: mariage de raison, mariage sans raison ', in Guézou, O., Manson, S. (eds.) Droit public et nucléaire, Ed. Bruylant, Bruxelles 2013, at p. 316.

${ }^{16}$ Art. 20, Par. 2.

${ }^{17}$ Art. 19, Par. 1

${ }^{18}$ Art. 21, Par. 2.

${ }^{19}$ Kamminga, M. 'The IAEA Convention on Nuclear Safety', International and Comparative Law Quarterly, 1995, at p. 874.

${ }^{20} 2006 / 2230$ (INI).

${ }^{21}$ O.J. of $2^{\text {nd }}$ August 2011, L 199/48.

${ }^{22} \mathrm{Graff}, \mathrm{T}$. 'Les modulations des principes du droit international face à la menace nucléaire', in: Guézou, O., Manson, S. (eds.). Droit public et nucléaire. Bruxelles: Bruylant, 2013, at pp. 136-138.

${ }^{23}$ The articles of this Planning Act of 2006 are now part of the Chapter II of Title IV of Book V of the Code of Environment.

${ }^{24}$ Report on the use of financial resources earmarked for the decommissioning of nuclear power plants, COM (2004)719 final.

${ }^{25}$ They are the Czech Republic, Finland, Hungary, Italy, Lithuania, the Netherlands, Slovakia, Slovenia, Spain and Sweden.

${ }^{26}$ Second Report on the use of financial resources earmarked for the decommissioning of nuclear installations, spent fuel and radioactive waste, p. 8.

${ }^{27}$ Commission Recommendation of 24 October, 2006, on the management of financial resources for the decommissioning of nuclear installations, spent fuel and radioactive waste [2006] OJ L 300/31. 
${ }^{28}$ Sec. 3, Par. 3.

${ }^{29}$ Reyners, P. 'Civil Liability for Long-Term Damage Caused by the Disposal of RAW', in Pelzer, N. (ed.): Schnittpunkte nationalen und internationalen Atomrechts, Nomos Verlag, Baden Baden 1997, at pp. 123-143.

${ }^{30}$ Pelzer, N. 'Regime of Liability and Compensation for Damage Arising out of Non-Retrievable Waste Disposal', in OECD (ed.): Nuclear Third Party Liability and Insurance, OECD, Paris 1985, at pp. 332-334.

${ }^{31}$ Art. 1, letter /a/.

${ }^{32}$ Art. I, Par. 1, letter /j/.

${ }^{33}$ Therefore, the Steering Committee for Nuclear Energy of the Organisation for Economic Co-operation and Development used its prerogative, anchored in the Paris Convention, and by its Decision of 11. 4. 1984, included those final disposal facilities being in the "pre-closure" phase into the application of this treaty.

${ }^{34}$ The Protocol to Amend the Vienna Convention on Civil Liability for Nuclear Liability of $12^{\text {th }}$ September 1997 entered into force on $3^{\text {rd }}$ October 2003.

${ }^{35}$ The Protocol to Amend the Paris Convention on Third Party Liability in the Field of Nuclear Energy of 12 February 2004 hasn't yet entered into force.

${ }^{36}$ Kissich, S. Internationales Atomhaftingsrecht, Anwendungsbereich und Haftungsprinzipien, Nomos Verlag, Baden Baden 2001, at pp. 166-167.

${ }^{37}$ The maximum liability of the operator in respect to damage caused by a nuclear incident shall be 15 million Special Drawing Rights under the Paris Convention of 1960. However, any Contracting Party, taking into account the possibility of the operator obtaining insurance or other financial security required and having regard to the nature of the nuclear installation or the nuclear substances involved (and to the likely consequences of an incident originating therefrom), may establish a lower amount, provided that in no event shall any amounts so established be less than 5, 000,000 Special Drawing Rights.

${ }^{38}$ The liability of the operator may be limited by the Contracting Party to not less than US \$5 million for any single nuclear incident. Any limits of liability which may be established pursuant to this Article shall not include any interest or costs awarded by a court in actions for compensation of nuclear damage. The United States dollar referred to in this Convention is a unit of account equivalent to the value of the United States dollar in terms of gold on 29 April 1963, that is to say US $\$ 35$ per one troy ounce of fine gold.

${ }^{39}$ Art. 10.

${ }^{40}$ Art. VII, Par. 1

${ }^{41}$ Emmerechts, S. 'Environmental Protection under Nuclear Law: Still a Long Way to Go', in OECD (ed.): International Nuclear Law: History Evolution and Outlook, OECD, Paris 2010,at pp. 142-143.

${ }^{42}$ Reyners, P. Civil Liability for Long-Term Damage Caused by the Disposal of Radioactive Waste, in Pelzer, N. (ed.) Schnittpunkte nationalen und internationalen Atomrechts, Baden-Baden: Nomos Verlag, 1997, at pp. 124-125.

${ }^{43}$ Dagicour, F. 'Une perspective Internationale de la gestion des déchets radioactifs' in Nuclear Law Under the Sign of Safety and Confidence, Archaeolingua, Budapest, 2001, at pp. 264-265.

${ }^{44}$ Streffer, C. et al. RAW, Technical and Normative Aspects of its Disposal, Springer, Berlin 2012, at p. 268.

${ }^{45}$ Segrestain, F. L' immersion des déchets radioactifs et le droit international, Université de Paris I, Paris 1980, at pp. 65-67. 